\title{
Reporting System in Transfusion Medicine - a Contribution to Patient Safety in the CLINOTEL Hospital Group
}

\author{
Andreas Becker Frank Thölen \\ CLINOTEL Krankenhausverbund gemeinnützige $\mathrm{GmbH}$, Cologne, Germany
}

\section{Key Words \\ Patient safety · Blood supply}

\section{Summary}

The members of the non-profit CLINOTEL Hospital Group have particularly high standards as regards the quality of patient care. These standards are based on a common understanding of quality in patient care that is also reflected in the quality policy of the individual member hospitals and which is in line with our motto 'Learn from the best, be one of the best'. We understand quality in its various dimensions; this means appropriate patient care in accordance with the latest medical knowledge and the best practice available. The individual values and expectations of the patients must be considered as an expression of respect for the individual and as a basic prerequisite for fulfilment of the expectations on us. Medical and nursing services must be provided with particular consideration for patient safety; the avoidance of damage must be given the highest priority. The reporting system presented is in line with our values and rounds off our activities in the field of quality assurance in transfusion medicine in the form of a preventative approach.

\section{Preliminary Remarks}

The non-profit CLINOTEL Hospital Group has been supporting its members in the implementation of quality requirements in transfusion medicine since 2008. Patient safety is at

\author{
Schlüsselwörter \\ Patientensicherheit · Blutversorgung
}

\section{Zusammenfassung}

Die Mitglieder des CLINOTEL-Krankenhausverbunds haben einen besonders hohen Anspruch an die Qualität der Patientenversorgung. Diesem Anspruch liegt ein gemeinsames Qualitätsverständnis der Patientenversorgung zu Grunde, das sich auch in der Qualitätspolitik der einzelnen Mitgliedshäuser widerspiegelt und unserem Leitbild "Von den Besten lernen, zu den Besten gehören» entspricht. Wir verstehen Qualität in ihren verschiedenen Dimensionen, dies bedeutet eine angemessene Patientenversorgung in Übereinstimmung mit dem aktuellen medizinischen Wissen und der besten verfügbaren Praxis. Die individuellen Wertvorstellungen und Erwartungen der Patienten sind zu berücksichtigen als Ausdruck der Achtung vor dem Individuum und als Grundvoraussetzung zur Erfüllung der an uns gestellten Erwartungen. Ärztliche und pflegerische Leistungen müssen unter besonderer Berücksichtigung der Patientensicherheit erbracht werden; die Vermeidung von Schaden hat höchste Priorität. Mit dem vorgestellten Meldesystem entsprechen wir unseren Wertvorstellungen und vervollständigen unsere Aktivitäten zur Qualitätssicherung in der Transfusionsmedizin im Sinne eines präventiven Ansatzes.

the forefront throughout the entire process, from the diagnosis through to aftercare. Thus far, support has taken the form of 'clinical implementation' of the requirements under the German Transfusion Act (Transfusionsgesetz; TFG) and the Directive of the Federal Medical Council (Bundesärztekam-

\section{KARGER}

Fax +497614520714

Information@Karger.de

www.karger.com (c) 2010 S. Karger GmbH, Freiburg

Accessible online at:

www.karger.com/tmh 
mer; BÄK), clinical audits with the involvement of recognised specialists from the CLINOTEL Hospital Group, the provision of key data from quality assurance with routine data, and the involvement of the Specialist Group Transfusion Medicine. To round off our activities, a reporting system transfusion medicine has now been established with the aim of continuously further improving the already high safety levels in transfusions within the CLINOTEL Hospital Group.

\section{Introduction}

The use of blood and blood products is a clinical area fraught with risk in which patient safety can be impaired. This is shown for example by the annual publications of the 'Serious Hazards of Transfusion (SHOT) Steering Group [1]' based on data from the long-standing British reporting system. These reports are characterised by excellent data material from the underlying reporting system which enables extensive information on the various undesired occurrences and side effects. Above all, the naming of the causes and the possible preventative measures make the annual publications a 'must have' the information and knowledge of which should be imparted to all involved in the recovery and use of blood products within the scope of clinical risk management.

The German TFG regulates the recovery of blood and blood constituents as well as the use of blood products. The aim of the TFG is to ensure safe recovery of blood and blood constituents as well as the secure and reliable supply of the population with blood products. Based on Sections 12a and 18 TFG, the BÄK presents the generally recognised state of knowledge in medical science and technology in directives above all for (extract)

- the recovery of blood and blood constituents,

- the use of blood products, including documentation of the indication on which the use is based,

- quality assurance relating to the use of blood products in medical care facilities and its monitoring by the medical profession,

- the qualification and duties of persons whose work is closely related to the use of blood products,

- the handling of non-used blood products in medical care facilities.

The BÄK does this by publishing the 'Directive of the Federal Medical Council on the Obtaining of Blood and Blood Constituents and on the Use of Blood Products (Haemotherapy)' (RLB) and the 'Cross-Sectional Guidelines on Therapy using Blood Constituents and Plasma Derivatives - General Amendment 2008' (QL BÄK). These guidelines provide a comprehensive overview of relevant aspects; in particular the comments on the diagnoses are important for clinical use.

A retrospective study by Greinacher [2] determined 32 cases of confusion during transfusions; this represents a rate of 1:32,000 erythrocyte concentrate transfusions. In 16 of these cases, the confusion occurred between bedside test and transfusion.

Krombach et al. [3] reported on the causes of the (fatal) confusion of stored blood or patient at a university clinic and also quotes further interesting figures in this respect: The incidence of an ABO-incompatible blood transfusion was 4 per 50,000 transfusions of erythrocyte concentrate. Based on a survey of 24 German hospitals, Caspari et al. [4] (2002) estimated the incidence of an ABO-incompatible blood transfusion as being 1:36,000. Figures from the USA show that the risk of a fatal confusion of patient or stored blood is between 1:600,000 and 1:800,000 blood transfusions In the USA, the incidence of non-fatal errors is between 1:12,000 and 1:19,000 transfusions [5].

Oldham et al. [6] compiled relevant aspects of transfusion safety for nursing personnel and midwifes. An editorial in the Lancet [7] comments on the importance of increasing the safety of blood products. This issue also includes three general works on erythrocyte concentrations by Klein et al. [8], on thrombocytes by Stroncek and Rebulla [9], and on coagulation factors by Key and Negrier [10], which deal extensively above all with the indication for the use of these products.

Hasskarl and Ostertag [11] provided an overview of the requirements in terms of clarification and documentation when giving blood and when using blood products.

In a work on the subject 'Safety of Blood Transfusions', Fopp and Wernli [12] reported that the three greatest risks for the recipient of blood are excessive volume, incorrect transfusion, and bacterial contamination.

Further works on risks and errors which are also based on SHOT data have been published by Hendrickson and Hiller [13] (2009), Stainsby [14-16], Stainsby et al. [17, 18], and Callum et al. [19].

Lundy et al. [20] and Linden et al. [21] reported on errors within the framework of transfusions as an opportunity to learn from others.

Zeiler [22] and Kaplan [23] commented on error analysis as an instrument of quality management in transfusion medicine.

The German Interdisciplinary Study Group for Clinical Haemotherapy (IAKH; www.iakh.de) has set up a national error register for blood transfusions on its website. This has been active as beta version since February 2009 [24].

\section{Reporting System Transfusion Medicine}

After discussing the knowledge gained from the audit processes and the key data from quality assurance with routine data in our Specialist Group Transfusion Medicine, the Reporting System Transfusion Medicine has been established in the CLINOTEL Hospital Group to enable all members to learn from corresponding case situations. One result is that the previous activities are to be supplemented by a reporting 
system which should be able to record relevant information on corresponding case situations and communicate the knowledge gained quickly and purposefully to all members by means of so-called clinical alarms (based on the 'Quick Alerts' of the Swiss Foundation for Patient Safety. Research date October 12, 2009 www.patientensicherheit.ch/de/aktuelles/index. $h t m l)$. The contact persons for the procedure in the member facilities are transfusion managers and quality managers as per TFG or RLB; the transfusion managers are also members of the Specialist Group Transfusion Medicine.

\section{What Can Be Reported and How?}

The transfusion managers contact a member of the medical staff at the CLINOTEL office as soon as a case gives them 'cause for concern' that patient safety could have been or has been impaired. It does not make any difference whether this involves unsafe actions by people or a defective technical device. The mere uncertainty regarding whether a case or an occurrence should be notified and analysed should result in contact being made. The principle to be applied is: 'In case of doubt contact us!'

We do not wish to operate a policy of selection; this involves a risk of important information not being taken into account, thus preventing learning from others. There is a simple formula for the 'PaSOS (Patient Safety Optimisation System)' reporting system of the German Society for Anaesthesia and Intensive Medicine (DGAI): 'Report everything that you wish you had known beforehand.' Rall [25] commented further in this context: 'Fundamentally speaking, it would appear advisable to report all "safety-relevant" occurrences. Any occurrence that has actually endangered patient safety or which could have endangered it in other circumstances can be of relevance to safety. The mere potential to cause harm is always a sufficient criterion. In this context, safety-relevant occurrences can also be positive examples and solutions. As professional employees, the persons reporting decide for themselves, within the scope of an anonymous and voluntary system, which events are "safety-relevant" for them. Even if negative occurrences are traditionally more likely to be reported and analysed than good solutions, Incident Reporting Systems should also record these positive occurrences and systematically analyse their coming about and their possible replication. If one understands incidents in the original sense of the word as unexpected, nonroutine occurrences, then the term also applies to the positive variety. Seen in this way, negative and positive occurrences are safety-relevant occurrences, although people prefer to learn from good solutions.'

\section{Case Discussion}

The purpose of contacting the CLINOTEL office as mentioned above is to agree a telephone appointment for discussion of the case which we consider to be the core of the system. During this discussion of the case which is based on the principles of systematic case analysis as per Taylor-Adams and Vincent [26], the relevant information and conclusions are prepared together with the expert from the member hospital. The task of the correspondingly trained representative of the CLINOTEL office attending the meeting is to manage the case discussion systematically in accordance with a checklist in order to enable precise preparation of the following content.

\section{Occurrence. What Has Happened?}

Effect: What effects has the occurrence had or could it have had?

Triggering event: Were there one or more unsafe actions? Were there technical faults? Other?

Latent or acute contributing factors related to the work environment or working conditions? Other?

Knowledge: What have you learned? What would be your recommendation to another hospital?

The focus of the case discussion is the determination of the (latent) factors which have contributed to an unsafe action as only these can form the basis of a preventative approach.

\section{Clinical Alarm}

The CLINOTEL office summarises the information prepared and supplements it with comments from specialist literature or known good clinical practice from a member hospital. The resulting clinical alarm is then sent to the members of the Specialist Group Transfusion Medicine as an attachment to an e-mail.

\section{Confidentiality}

No records or files contain any reference in their content or their file name to the hospital or person making the notification. Identification is exclusively via a number that we take from a randomly generated list. The contact persons are requested to keep the number assigned, at least until the clinical alarm has been sent. Without this number, the CLINOTEL office is unable to allocate and process the case, for example in the event of information being submitted at a later date. Handwritten records made during the case discussion are destroyed immediately by suitable means once the information has been transferred to a file. No further records are kept; the process is regulated in an internal manual.

\section{Disclosure}

The authors declared no conflict of interest. 


\section{References}

1 The Serious Hazards of Transfusion (SHOT) Steering Group. Annual Report 2008. Research date 12.10.2009: www.shotuk.org.

2 Greinacher A: Technik der Bluttransfusion; in Mueller-Eckhardt C, Kiefel V (Hrsg): Transfusionsmedizin. Heidelberg, Springer, 2003, pp 329-337.

3 Krombach J, et al: Human error: the persisting risk of blood transfusion: a report of five cases. Anest Analg 2002;94:154-156.

4 Caspari G, et al: The risk of transfusion to the wrong patient in Germany. Transfusion 2002;42:1238-1239.

5 Linden JV, et al: Transfusion errors in New York State: an analysis of 10 years' experience. Transfusion 2000;40:1207-1213.

6 Oldham J, et al: Right patient, right blood, right care: safe transfusion practice. Br J Nurs 2009;118: 312-320.

7 Improving blood safety worldwide. Lancet 2007; 370:361.

8 Klein HG, et al: Transfusion medicine 1: red blood cell transfusion in clinical practice. Lancet 2007;370: 415-426.

$\checkmark 9$ Stroncek DF, Rebulla P: Transfusion medicine 2: platelet transfusions. Lancet 2007;370:427-438.

10 Key NS, Negrier C: Transfusion medicine 3: coagulation factor concentrates: past, present, and future. Lancet 2007;370:439-448.
11 Hasskarl H, Ostertag A: Anforderungen an die Aufklärung und Dokumentation bei der Blutspende und bei der Anwendung von Blutprodukten. PharmR 2006;28:311-324.

12 Fopp M, Wernli M: Sicherheit der Bluttransfusion heute. Swiss Medical Forum 2006;6:139-144.

13 Hendrickson JE, Hillyer CD: Noninfectious serious hazards of transfusion. Anesth Analg 2009;108: 759-769.

14 Stainsby D: ABO incompatible transfusions - experience from the UK Serious Hazards of Transfusion (SHOT) scheme Transfusions ABO Incompatible. Trans Clin Biol 2005;12:385-388.

15 Stainsby D: Errors in transfusion medicine. Anesth Clin N Am 2005;23:253-261.

16 Stainsby D: Haemovigilance in the United Kingdom and Europe. Hematol J 2004;5:175-178.

17 Stainsby D, et al: Reducing adverse events in blood transfusion. Br J Haematol 2005;131:8-12.

8 Stainsby D, et al: 6 years of shot reporting - its influence on UK blood safety. Transfus Apher Sci 2004;31:123-131.

19 Callum L, et al: Reporting of near-miss events for transfusion medicine: improving transfusion safety. Transfusion 2001;41:1204-1211.
20 Lundy D, et al: Seven hundred and fifty-nine (759) chances to learn: a 3-year pilot project to analyse transfusion-related near-miss events in the Republic of Ireland. Vox Sang 2007;92:233-241.

21 Linden JV, et al: A report of 104 transfusion errors in New York State. Transfusion 1992;32:601-606.

22 Zeiler T: Fehleranalyse als Instrument des transfusionsmedizinischen Qualitätsmanagements. Gesundh Ökon Qual Manag 2006;11:25-29.

23 Kaplan HS: Getting the right blood to the right patient: the contribution of near-miss event reporting and barrier analysis. Transfus Clin Biol 2005; 12:380-384.

24 Fritsch T: Aufruf zur Teilnahme: Einrichtung eines nationalen Fehlerregisters für Bluttransfusionen der DIVI und der IAKH in Zusammenarbeit mit dem PaSOS System der DGAI. Anästhiol Intensivmed 2009;50:66.

25 Rall M: Fehler in der Intensivmedizin. Sind wir lernfähig? Intensivmed Notfallmed 2009;46:318-329.

26 Taylor-Adams S, Vincent C: Systemanalyse klinischer Zwischenfälle. Das London-Protokoll. Publisher of the German translation: Swiss Foundation for Patient Safety, February 2007. www.patientensicherheit.ch/de/projekte/londonprotocol_d.pdf. 